Finnish Economic Papers - Volume 19 - Number 1 - Spring 2006

\title{
TAXATION, GROWTH AND WELFARE: DYNAMIC EFFECTS OF ESTONIA'S 2000 INCOME TAX ACT*
}

\author{
MICHAEL FUNKE \\ Department of Economics, Hamburg University, \\ Von-Melle-Park 5,D-20146 Hamburg, Germany, \\ Email:funke@econ.uni-hamburg.de \\ and \\ HOLGER STRULIK \\ Department of Economics, Hannover University, \\ Königsworther Platz 1, D-30167 Hannover, Germany, \\ Email:strulik@vwl.uni-hannover.de
}

\begin{abstract}
This paper analyses the long-run effects of Estonia's 2000 Income Tax Act with a dynamic general equilibrium model. Specifically, we consider the impact of the shift from an imputation system to one where companies only pay taxes on distributed profits. Balanced growth paths, transitional dynamics and welfare costs are computed. Our results indicate that the 2000 Income Tax Act leads to higher per capita income and investment, but lower welfare. A sensitivity analysis shows that the results are rather robust. (JEL: H25, H32, O41, O52)
\end{abstract}

\section{Introduction}

The debate over how favourably tax codes should treat capital is an established part of political discourse in many countries. The controversy has been particularly vigorous in the setting of tax reform agendas of transition economies. The World Bank (2000) suggests that the design of tax systems should be guided by tested theory and the lessons of experience, i.e. a broad-based tax system with low statutory rates. This approach advocates the elimination of tax exemptions for favoured enterprises to

\footnotetext{
* We would like to thank the editor and two anonymous referees for helpful comments on an earlier draft. The usual disclaimer applies.
}

harden budget constraints, reduction of the tax burden on viable enterprises, encouraging investment and promotion of long-term growth.

Economists have only recently developed tools to assess the impacts of tax reform on long-term growth. Chamley $(1981,1986)$ presented the earliest general equilibrium analysis of the effects of capital taxation and focusing on the welfare consequences of eliminating a tax on capital. Judd (1987) followed with a different approach that compared the welfare cost associated with the taxation of capital and labour income. Both studies (and numerous others) found significant welfare gains associated with the reduction of capital income taxation. 


\section{Finnish Economic Papers 1/2006 - Michael Funke and Holger Strulik}

In this paper, we transpose to Estonia Strulik's (2003a) exogenous growth model that was originally used to analyse Germany's recent corporate tax reform. The objectives of this exercise are, first, to outline a dynamic supply-sideoriented general equilibrium model that allows us to address the question of how changes in the capital income tax rate affect the well-being of households, and second, to illustrate the potential magnitude of the gains that accompany Estonia's 2000 income tax act. This approach also allows us to address a widely neglected issue - transition dynamics. ${ }^{1}$

Various growth models show lower taxation unambiguously increases investment and economic growth. Few, however, indicate such tax policy has a positive impact on welfare, i.e. the models do not derive the foregone consumption necessary to achieve a distinct and higher steady-state growth path. Thus, even if the theoretical growth literature indicates that lower taxation results in a new higher steady-state income, there may well be only minute, or even negative, welfare gains if the shift involves large adjustment costs and high foregone consumption (e.g., Lucas, 1990, and Strulik, 2003b).

In the following analysis, we consider Estonia's 2000 income tax reform in the long run, taking into account general equilibrium feedback effects. In an earlier partial equilibrium paper (Funke, 2002), Tobin's $q$ theory of investment was applied to analyse the investment effects of the 2000 tax reform in Estonia. The numerical simulations of the calibrated model find a $6.1 \%$ increase in the Estonian equipment capital stock. While the model provides clear insights into an important policy issue at relatively low cost in terms of technical complexity, it is limited for our purposes here because it abstracts from general equilibrium responses when evaluating the tax policy. It does not quantify the economic benefits and costs of the reform arising from macroeconomic repercussions.

The remainder of this paper is organized as follows: Section 2 briefly describes the Estonian 2000 income tax reform. Section 3 provides a

1 Strulik (2003b) shows that the welfare effects of tax changes in endogenous growth models are quite similar to those in growth models with exogenous technological progress. survey of current corporate tax rates in Eastern Europe. Section 4 lays out the baseline model. Section 5 proposes a numerical exercise, wherein we calibrate the model, provide sensitivity analysis with respect to parameter specification and compute welfare costs. Following analysis of the benchmark model, our focus shifts to foreign direct investment in section 6. Section 7 presents some empirical evidence and Section 8 summarises our main findings.

\section{Estonia's 2000 income tax act}

Most prevailing tax legislation in Estonia was enacted during the first phase of transition reforms. The Law on Taxation entered into effect in 1994 and has since been amended several times. The Income Tax Act (Tulumaksuseadus) was passed December 15, 1999, and went into effect in January 2000.

Estonia's 1994 tax code applied a flat tax rate of $26 \%$ to businesses, personal earnings and capital gains. ${ }^{2}$ It contained depreciation allowances of up to $40 \%$ for equipment and up to $8 \%$ for buildings. Additionally, there was a loss-carry-forward possibility over a period of five years. The personal income tax rate was $26 \%$. When companies paid dividends, they had to pay an additional tax rate of $26 / 74$ (i.e. 26 kroons for every 74 kroons) on net dividends and shareholders received a dividend tax credit. ${ }^{3}$ The effect of this dividend credit system was that distributed profits were taxed at the shareholder's personal rate of income tax rather than under a corporation tax. Thus, the system worked like an imputation system,

2 The tax-free income of a resident natural person is 12,000 Estonian kroons, implying that the marginal income tax rate is either $0 \%$ or $26 \%$, and the average income tax rate is somewhere between $0 \%$ and $26 \%$.

3 If the after-tax dividend was 74 kroons, then the corporation had to pay 26 kroons in taxes on the dividend. The tax rate of 26/74 thus equals a $26 \%$ personal income tax rate. Summaries of the Estonian tax system are available in Ebrill and Havrylyshyn (1999), IMF (2000), pp. 35-48, Kesti (1995) and Sorainen et al. (2002). On October 24, 2001, the Estonian Parliament passed amendments to Income Tax Act, which include modifications to the regulation concerning the taxation of dividends. Since January 1 , 2003, all dividends, regardless of the recipient, are subject to the 26/74 income tax, including dividends paid to resident legal persons (see Sorainen, 2002, p. 99). 
Finnish Economic Papers 1/2006 - Michael Funke and Holger Strulik

Table 1. International Comparison of Corporate Taxation in Eastern Europe in 2003

\begin{tabular}{|l|c|l|l|}
\hline Country & $\begin{array}{l}\text { Corporate Tax Rate } \\
\text { for Retained } \\
\text { Earnings, (\%) }\end{array}$ & $\begin{array}{l}\text { Share of Corporate } \\
\text { Taxes in Total } \\
\text { Tax Revenues, (\%) }\end{array}$ & $\begin{array}{l}\text { Tax Depreciation Rules for } \\
\text { Machinery and Equipment }\end{array}$ \\
\hline Bulgaria & 15 & 6.40 & Straight-line depreciation in 5 years \\
Croatia & 20 & 2.57 & Straight-line depreciation (4-10 years) \\
Czech Republic & 31 & 8.30 & Geometric-degressive depreciation (12 years)* \\
Estonia & 0 & 3.58 & - \\
Hungary & 18 & 6.92 & Straight-line depreciation (20\%) \\
Latvia & 15 & 3.72 & Straight-line depreciation $(20-40 \%)$ \\
Lithuania & 5 & 8.02 & Straight-line depreciation $(4-10$ years) \\
Poland & 22 & 11.43 & Geometric-degressive depreciation $(20 \%)$ \\
Romania & 25 & 11.69 & Straight-line depreciation in 10 years \\
Russia & 35 & Straight-line depreciation in 4-10 years \\
Slovak Republic & 25 & 3.09 & Straight-line depreciation in 15 years \\
Slovenia & 25 & Straight-line depreciation in 4-10 years \\
\hline
\end{tabular}

Notes: *The depreciation rate amounts to $8.33 \%$ for the first year and $15.28 \%, 13.89 \%, 12.5 \%, 11.11 \%, 9.72 \%, 8.33 \%$, $6.94 \%, 5.56 \%, 4.17 \%, 2.78 \%$ and $1.39 \%$ for subsequent years. The share of corporate taxes in total tax revenues in 2000 was calculated using revenue data from the IMF.

Sources: PriceWaterhouseCoopers (2002). Corporate Taxes - Worldwide Summaries 2002-2003. New Jersey: John Wiley \& Sons.; IMF. Government Finance Statistics Yearbook 2001. Washington.; Nam and Radulescu (2003).

where the rate of imputation was the corporation tax rate.

The 2000 income tax act turned Estonia's income tax approach on its head. Under the act, resident companies and permanent establishments of foreign entities (including branches) are subject to income tax for distributions (both actual and deemed). Distributions include dividends and other profit distributions, fringe benefits, gifts, donations, representation expenses, and expenses and payments unrelated to business. However, the new Estonian corporate income tax does not constitute a tax exemption, rather the taxation of profits is postponed until a distribution of profits occurs.

The flat tax rate for all distributions is $26 / 74$ on net dividends. The transfer of assets of the permanent establishment to its head office or to other non-residents is also treated as a distribution. Dividends paid to non-residents are additionally liable to withholding tax at the general rate of $26 \%$, unless the non-resident legal entity holds at least $25 \%$ of the share capital of the distributing Estonian company. Under the income tax legislation, therefore, corporate entities are exempt from income tax on undistributed profits, regardless of whether these are reinvested or merely retained. Since there are no taxes on corporate income per se, there is no need for depreciation allowances. Capital gains realised by a resident corporate entity (includ- ing non-resident permanent establishment) are not taxed until the actual or hidden distribution occurs and are subject to 26/74 income tax on a monthly basis. Estonia has no thin capitalisation rules.

\section{Comparison of corporate taxation in Eastern Europe}

Table 1 compares the corporate tax rate for retained earnings, the share of corporate taxes in total tax revenues and the tax depreciation methods applied in twelve Eastern European transition economies. Eastern European states have implemented a series of corporate tax reforms, which have been justified mainly in the context of tax competition. Considering the statutory corporate tax rate for retained earnings, Russia ranks first at $35 \%$, followed by the Czech Republic at $31 \%$, and then Romania, the Slovak Republic and Slovenia at 25\%. The corporate tax rate for retained earnings is lowest in Estonia $(0 \%)$. In most countries, straight-line depreciation can be adopted for machinery and equipment. On the contrary, geometric-degressive depreciation is usually applied for machinery and equipment in the Czech Republic and Poland. ${ }^{4}$

4 As taxes on corporate income per se were eliminated after 1 January 2000 in Estonia, there is no need for depreciation allowances. 


\section{Finnish Economic Papers 1/2006 - Michael Funke and Holger Strulik}

While these tax rates provide an interesting snapshot of corporate taxation around Eastern Europe, we should remember that a low tax rate does not necessarily mean a low tax burden. For individual countries, the tax rate must be applied to the tax base to measure tax burdens. That said, in the absence of harmonised tax bases, a comparison of tax rates only gives a partial impression of international tax burdens. We therefore also provide the share of corporate taxes in total tax revenues in 2000.

The comparison reveals that the Estonian corporate tax system provides rather favourable conditions for investors and tends to promote private investment that is financed by retained earnings. This positive assessment of corporate taxation in Estonia is further substantiated by the share of corporate taxes in total tax revenues and the qualitative tax measures published by the EBRD (2002) and the review of tax reform experiences in Stepanyan (2003). ${ }^{5}$

\section{A dynamic general equilibrium model}

To get a handle on some of the issues raised in the introduction, we develop an intertemporal model of optimal growth with three sectors: the state, firms and households. In order to discuss the issues raised in the introduction, we augment a standard neoclassical growth model with a set of fiscal policy parameters. Especially, the model covers a variety of taxes on retained earnings, dividends and consumption, and can thus provide insights into how and to what extent the 2000 income tax act might influence a firm's investment decisions, output and consumption. Our decision to exclude consideration of how the financial structure and financial policies of a firm are affected by the tax reform is motivated by our wish to treat one difficulty at a time and to simplify our analysis. We outline the features of the model in terms of the objectives and constraints various agents are facing. The model is determinis-

5 The investment climate survey of the Worldbank (see http://rru.worldbank.org/investmentclimate/) provides a snapshot of how firms perceive the tax environment in various countries.

28 tic and agents have perfect (point) expectations of future variables.

The model has a single production sector. The representative firm acts optimally by choosing its real investment so as to maximise an objective function. To define the objective function of the firm, we need to determine its net-of-tax cash flow at each time. The firm is assumed to produce output with capital, $K$, and labour, $L$, using a Cobb-Douglas production function. The technology parameter $A$ grows at an exogenous rate $\gamma$ and the firm faces expenses for labour, $w L$. As a result of these assumptions, and taking the output price as a numeraire, economic profits of the firm are given by

(1) $\pi=K^{\alpha}(A L)^{1-\alpha}-w L-\delta K$,

where $\delta$ is the (geometric) economic depreciation rate. We carefully distinguish in the model between economic depreciation and depreciation for tax purposes. Following Sinn (1987), tax depreciation is divided up into a part $z$ of gross investment that is written off immediately and the remainder $(1-z)$ that depreciates at the economic rate. Hence with $I$ denoting net investment, current depreciation for tax purposes is given by $z(I+\delta K)+(1-z) \delta K$ or equivalently $z I+\delta K$. On the dividend side, gross dividends are defined as

(2) $D=\pi-I-T$,

where corporate taxes on retained earnings are defined as

(3) $T=\tau(\pi-z l-D)$.

Equations (1) - (3) imply that in every period we have

(4) $D=K^{\alpha}(K, A L)^{l-\alpha}-w L-\delta K-\frac{(1-\tau z) I}{1-\tau}$.

The optimal behaviour of the firm depends upon both the personal tax rate and the corporate tax rate. ${ }^{6}$ We therefore define the tax system in

6 Adding corporate taxation could affect the firm's ideal capital structure, as well. A particularity of the Estonian tax system is the absence of a tax advantage of debt finance. Standard reasoning employing the tax channel (Sinn, 1987) suggests that Estonian firms should strictly prefer to finance 
terms of these two tax rates. The first, defined above, is the corporate tax rate for retained earnings $(\tau)$. The second measures the degree of discrimination between earnings retentions and dividend payments. This "tax discrimination variable" is denoted by $\theta$ and is defined as the opportunity cost of retained earnings in terms of net dividends $(\theta D)$ foregone. ${ }^{7}$ Thus, if the Estonian firm distributes one kroon $(E E K)$, the shareholder receives $\theta E E K$ in after-tax dividends. For an imputation system, this tax discrimination variable is given as

(5) $\theta=\frac{1-m}{1-\tau}$

where $m$ is the personal tax rate on dividends. Equation (5) allows a straightforward taxonomy of corporate tax systems. Dividends are tax-favoured when $\theta>1$, while for $\theta<1$ a preferential tax treatment of retained earnings exist. When $\theta=1$ and $z=0$, the corporate tax system is neutral with respect to retentions and distributions. Firms are assumed to maximise the discounted stream of after-tax dividends, i.e.

(6) $V(0)=\int_{0}^{\infty} \theta D_{e}^{-\int_{t}^{v}(1-m) r(s) d s} d v$.

The interest rate $r$ is assumed to be exogenously given for the firm. In choosing its policies, the firm has to satisfy a number of technological and legal constraints. The most obvious constraint is that net investment $(I)$ increases the capital stock and therefore the evolution of capital is given by

\section{(7) $\dot{K}=I$.}

We can now apply the standard techniques of optimal control theory, and solve the firm's maximisation problem or the path of controls,

investment by internal funds. Thus, existing debt finance has to be explained by forces exogenous to the model, e.g. asymmetric information. Myers and Mailuf (1984), for example, provide a pecking order of capital structure. Under this view, information problems dominate the process of raising funds. The cheapest source of finance is internal funds. Among external sources of funds, debt is cheaper than equity since issuing equity is considered to send a negative signal about managers' opinions regarding the firm's future prospects. Modelling such asymmetric information issues is beyond the scope of the paper.

7 For a detailed discussion, see King (1977), pp. 47-56, and King and Fullerton (1984), pp. 21-22. given the tax rate. The necessary first-order conditions for optimality yields the capital user cost condition

(8) $\alpha[K /(A L)]^{\alpha-1}-\delta=\theta(1-\tau z) r$.

Equation (8) equates the net return of spending one $E E K$ for equity versus bonds. The representative forward-looking household is infinitively lived and maximises utility over an infinite horizon, as summarised by the following functional form

(9) $U=\int_{0}^{\infty} \frac{C^{l-\sigma}}{1-\sigma} e^{-\rho t} d t$,

where $C$ denotes consumption, $\rho$ is the time preference rate taken to be constant in all periods, and $1 / \sigma$ is the intertemporal elasticity of substitution. Thus, the determination of optimal consumption is fundamentally an intertemporal problem. Note that we are abstracting from consumer durables here, i.e. consumption services that yield utility are identical to purchases of consumer goods.

Household financial wealth $(W)$ consists of equity $(V)$ and bonds $(B)$. The accumulation of bonds is therefore constrained by the dynamic budget constraint

$$
\begin{aligned}
& \dot{B}=(1-m) w+(1-m) r B+\theta D+Z \\
& -\left(1+\tau_{c}\right) C
\end{aligned}
$$

where $Z$ denotes lump-sum transfers from the government and $\tau c$ is the tax on consumption purchases. Inserting $\dot{V}$ obtained from differentiating (6) yields the law of motion for wealth as

(11)

$\dot{W}=(1-m) w+(1-m) r W+Z-\left(1+\tau_{c}\right) C$.

With the particular specification of preferences above, the first-order condition is given by the Ramsey rule

$$
\frac{\dot{C}}{C}=\frac{r(1-m)-\rho}{\sigma} .
$$

The government finances expenditures $G$ by taxes and issue of bonds $\left(B^{G}\right)$. Its budget constraint is given by 
Finnish Economic Papers 1/2006 - Michael Funke and Holger Strulik

$$
\begin{aligned}
& G+r G^{G}=\dot{B}^{G}+m\left[w L+r B^{G}+r B+\frac{D}{(1-\tau)}\right] \\
& +\tau_{C} C+\tau(\pi-z l-D),
\end{aligned}
$$

sented by a time series of transfers. Since labour supply is normalised to one, GDP is obtained as $Y=K^{\alpha} A^{1-\alpha}$. It is used for private consumption $(C)$, investment $(I)$ and government consumption $(G)$, i.e. $I=(1-g) K^{\alpha} A^{1-\alpha}-C-\delta K$. Uswhere the left-hand side displays uses of revenue (purchases and debt payments) and the right-hand side displays tax revenue and newly issued debt. The government faces also a no Ponzi-game constraint which implies that the present value of expenditures equals the present value of tax revenue plus initial debt. Government debt is "Ricardian" in the sense that given initial debt, tax rates, and expenditure, the competitive equilibrium can be represented either by a government debt path or by the amount of transfers to households $(\mathrm{Z})$ required to balance the government budget at any time:

$$
\begin{aligned}
& Z=m\left[w L+r B^{G}+r B+\frac{D}{(1-\tau)}\right] \\
& +\tau_{C} C+\tau(\pi-z l-D)-G
\end{aligned}
$$

For the benchmark case we assume that the government finances a constant share of public consumption $G=g Y$. If a government finances a constant amount of public consumption $G$ in an economy that shows perpetual growth of income $Y$, the inevitable result is that the government share of GDP, $g=G / Y$, converges towards zero asymptotically. In order to avoid this counterfactual result, most calibration studies - like ours - assume a constant share $g$ of government expenditure. This way, government expenditure is allowed to expand with GDP like consumption and investment with long-term constant shares of all parts, a natural steady-state result. ${ }^{8}$

The government finances a constant share of government consumption $G=g Y$ with tax earnings and issues of bonds. Given Ricardian equivalence, the path of government debt necessary to balance the current budget can then be repre-

8 Furthermore, the assumption of a constant share of public consumption is consistent with the empirical facts for the period 1997-2004 in Estonia (see http://pub.stat.ee/pxweb.2001/I_Databas/Economy/Economy.asp). Note that the unique role of transfers is to balance the government budget and to close the model, i.e. transfers vary with the exogenous parameter $\mathrm{g}$ that pre-determines the path of government expenditure, gY. This way, the paper presents an exercise in positive theory of taxation by estimating effects of a given policy reform. It does not provide an answer to the normative question of what choice of taxes and transfers would maximize consumer utility (as e.g. in Coleman, 2000). ing this equation to substitute $I$ in $\dot{K}=I$, which is equation (7), and then dividing the result by $K$ provides capital accumulation according to

(15) $\frac{\dot{K}}{k}=(1-g)(K / A)^{\alpha-1}-(C / K)-\delta$.

For equilibrium analysis, we use the following transformed variables: $c \equiv C / K$ and $k \equiv K / A L$. Using this change of variables and inserting $r$ from (8) implies that equation (12) and (15) can be rewritten as

$$
\frac{\dot{k}}{k}=(1-g) k^{\alpha-1}-c-\delta-\gamma
$$

and

$$
\text { (17) } \frac{\dot{c}}{c}=\frac{\phi\left(\alpha k^{\alpha-1}-\delta\right)-\rho}{\sigma}-\gamma-\frac{\dot{k}}{k} \text {, }
$$

where $\phi=(1-\tau) /(1-\tau z)$. Equations (16) and (17) are the two equations of motion driving the system, together with the transversality condition and initial $K(0)$ and $A(0)$. The unique steady state, $k^{*}$ and $c^{*}$, is defined by $\dot{c}=\dot{k}=0$, which implies

$$
k^{*}=\left[\frac{\gamma \sigma+\rho+\phi \delta}{\alpha \phi}\right]^{1 /(\alpha-1)}
$$

and

$$
c^{*}=(1-g) k^{* \alpha-1}-\gamma-\delta .
$$

From the linearisation of the above system, we see the model displays a saddle path dynamic structure, regardless of the tax rate. This implies that adjustment dynamics after a tax reform are uniquely determined as a movement along a stable manifold. One can also see from $\partial \phi / \partial \tau<0$ and $\partial k^{*} / \partial \phi>0$ that a corporate tax reduction unambiguously increases the capital stock in efficiency units. ${ }^{9}$ This can also be seen in the

9 We have abstracted from the question of the credibility of the reform. A more favourable tax treatment of capital generally encourages the accumulation of capital, but only if investors believe that the lower rates will remain in place. However, once the private sector has build up the capital stock in response to lower tax rates, the government faces 
capital user cost condition (8), where a tax reduction reduces the tax discrimination variable $\theta$. The equilibrium interest rate is given by

$$
r^{*}=\gamma \sigma+\rho
$$

To evaluate the welfare consequences of a change in tax policy, we report the equivalent variation $(E V)$ for an infinitively lived household. We normalise $A(0)=1$, use $(C / K) \cdot(K / A)=c k$ and write

$U=\int_{0}^{\infty} \frac{(C / A)^{1-\sigma} A^{1-\sigma} e^{-\rho t}}{1-\sigma} d t=\int_{0}^{\infty} \frac{(c k)^{1-\sigma} e^{-[\rho-\gamma(1-\sigma)]}}{1-\sigma} d t$

Following Lucas (1990, 2003), we measure the welfare gain as the percentage change in consumption that equates intertemporal utility from remaining in the pre-reform state compared to the post-reform state. We solve this numerical problem several times and decrease the maximum discretisation error of the employed Runge-Kutta method until a further decrease of the error does not lead to a reduction of the welfare gain by more than $10^{-5}$.

\section{Model parameterisation and cali- bration of the baseline model}

In this section, we seek to determine the extent to which the 2000 income tax act promotes or inhibits investment, consumption and welfare. The analysis is carried out through calibrations and numerical solutions that account for the effects of government policy without estimating real-economy parameters for the model. We first pin down the Estonian benchmark economy using parameters that are "calibrated" from data on actual allocations. This procedure establishes a benchmark equilibrium with existing tax rules and prices. Starting from this verified benchmark, we then calculate the effects (unanticipated) of the tax act.

an incentive to raise the tax rates on capital. Investors will realise this incentive and so will be wary of betting too much on the persistence of lower tax rates into the future.
We select the first values for the benchmark model from other calibration exercises, i.e. we adopt $\alpha=0.33$ and $\rho=0.02$. Following Rõõm (2001), the capital-output ratio has been assumed to be $(K / Y)^{*}=2.0$. Estonia's current $G D P$ growth rates have to be regarded as a temporary phenomenon, so we set the equilibrium growth rate to the average German value prior to unification $(\gamma=1.75 \%)$. The economic depreciation rate is set equal to $8.25 \%$. Admittedly, this figure is somewhat arbitrary, but nevertheless reasonable given that it is below the $10 \%$ rate of depreciation assumed by King and Rebelo (1990) and employed in much of the RBC literature, and further because it generates a fairly realistic investment ratio of $20 \%$. The value of $g$ is set to Estonia's share of government consumption in GDP (0.2) and the prereform depreciation rate for tax purposes to $d$ $=0.4$ as in Funke (2002). The pre-reform corporate tax rate for retained earnings is $\tau=0.26$, and the tax rate of wage and dividend income is $m=0.26$. The value-added tax rate is $\tau_{c}=$ 0.18 . For an asset life of ten years, the present value of tax depreciation allowances is then $\sum_{\mathrm{t}=1}^{9}\left\lfloor d(1-d)^{t-1} /(1+r)^{1}\right\rfloor+\left\lfloor(1-d)^{9} /(1+r)^{10}\right\rfloor$ in discrete time. A continuous time approximation is $y_{1}:=\int_{0}^{\infty} d e^{-d t} e^{-r t} d t=d /(r+d)$. The present value of economic tax depreciation allowances is $y_{2}:=\delta /(r+\delta)$, and hence the artificial variable for immediate write-offs, $z$, solves $y_{1}=z+(1-z) y_{2}$. The benchmark model implies $z=0.72$. Since we have already set the equilibrium growth rates, the capital-output ratio and therefore $r^{*}$, the remaining parameter $\sigma=\left[(1-\tau) r^{*}-\rho\right] / \gamma=3.0$ is endogenously determined. The resulting benchmark parameters are given in Table 2 below. We assume a particularly simple government sector, i.e. one where the government balances its budget each period. ${ }^{10}$ On the expenditure side, the government uses its proceeds to finance $g$. All remaining tax revenues are used for lump-sum transfers to the household sector.

10 The Estonian government is constitutionally obliged to maintain a balanced central budget. To plug revenue gaps, the government currently plans to introduce protective tariffs against non-EU countries, including the US. The goal is to confront possible budget deficits without raising interest rates or dampening investment and growth. 
Finnish Economic Papers 1/2006 - Michael Funke and Holger Strulik

Table 2. Benchmark Parameter Values

\begin{tabular}{|c|c|c|c|c|c|c|c|c|c|c|c|}
\hline$\alpha$ & $\varrho$ & $\gamma$ & $\sigma$ & $\delta$ & $\mathrm{g}$ & $\tau$ & $\mathrm{m}$ & $\mathrm{d}$ & $\tau \mathrm{c}$ & $(\mathrm{K} / \mathrm{Y})^{*}$ & $(\mathrm{I} / \mathrm{Y})^{*}$ \\
\hline 0.33 & 0.02 & 0.0175 & 3.0 & 0.082 & 0.2 & 0.26 & 0.26 & 0.4 & 0.18 & 2.0 & 0.2 \\
\hline
\end{tabular}

Table 3. Estonia's 2000 Income Tax Act - A Quantitative Assessment

\begin{tabular}{|c|c|c|c|c|c|c|c|}
\hline \multirow{2}{*}{ Parameter } & \multirow{2}{*}{$(I / Y)^{*}$} & \multirow{2}{*}{$k^{*}$} & \multicolumn{2}{|c|}{ Consumption } & \multicolumn{3}{|c|}{ Welfare Gain $(E V)$} \\
\hline & & & Impact & Long Run & Transitional & Steady State & Net \\
\hline Benchmark & 1.22 & 9.24 & -2.63 & 0.87 & -1.38 & 0.87 & -0.51 \\
\hline$g c^{*}=0.03^{\mathrm{a}}$ & 1.37 & 9.24 & -3.79 & 0.50 & -1.15 & 0.50 & -0.65 \\
\hline$g c^{*}=0.043^{\mathrm{b}}$ & 1.53 & 9.24 & -4.88 & 0.09 & -0.86 & 0.09 & -0.77 \\
\hline$(K / Y)^{*}=2.5$ & .096 & 5.76 & -2.90 & 0.09 & -0.59 & 0.09 & -0.50 \\
\hline$(K / Y)^{*}=1.5$ & 1.37 & 13.9 & -2.22 & 2.20 & -2.63 & 2.20 & -0.43 \\
\hline$d=0.2$ & 1.91 & 14.5 & -4.24 & 1.26 & -2.02 & 1.26 & -0.76 \\
\hline$d=0.6$ & 0.89 & 6.71 & -1.88 & 0.65 & -1.03 & 0.65 & -0.38 \\
\hline$\varrho=0.01$ & 1.22 & 9.24 & -2.38 & 0.87 & -1.36 & 0.87 & -0.49 \\
\hline$\varrho=0.02$ & 1.22 & 9.21 & -3.42 & 0.87 & -1.43 & 0.87 & -0.57 \\
\hline$\eta=1.67$ & 1.22 & 9.24 & -1.59 & 2.26 & -1.65 & 1.10 & -0.56 \\
\hline$\eta=2.48$ & 1.22 & 9.24 & -1.45 & 2.43 & -1.69 & 1.12 & -0.57 \\
\hline$\Delta \% \mathrm{G}$ const. & 1.22 & 9.24 & -2.24 & 1.85 & -0.81 & 0.89 & 0.08 \\
\hline
\end{tabular}

Notes: The table gives the deviations from pre-reform steady states in percentage points for $I / K$ and in per cent for other variables; a) $g_{c}{ }^{*}=0.03$ implies $(I / Y)^{*}=0.225$; b) $g_{c}{ }^{*}=0.043$ implies $(I / Y)^{*}=0.25$.

In our (unanticipated) policy scenario, we reduce the tax rate for retained earnings permanently from $26 \%$ to $0 \%$ and compare the results in all scenarios to the benchmark steady-state equilibrium with the initial tax rate in place. ${ }^{11}$ In order to assess the robustness of the estimates, we executed an extensive sensitivity analysis. Baseline parameter values are employed in all scenarios, except for the parameter subjected to sensitivity analysis. In table 3 we report the results.

The "prototypical" benchmark results for $\gamma=g_{c}=0.0175$ are given in the first row of Table 3 . When reducing the tax rate for retained earnings, equivalent variation declines by $0.51 \%$ over the infinite horizon. What is driving these results is the following. The removal of the tax rate for retained earnings increases investment expenditures. The increase of investment has an immediate impact upon consumption. In the short run, consumption decreases by $2.63 \%$ relative to the benchmark $(-2.63 \%)$. The transitional welfare effect is also negative

11 The tax discrimination variable prior to the reform is given by $\theta=(1-0.26) /(1-0.26)=1.0$, and $\theta=(1-0.26) /(1$ $0.0)=0.74$ effective January 1, 2000. The new tax system therefore implies a preferential treatment of retained earnings.

32
$(-1.38 \%)$. In the long run, however, consumption is increasing by $0.87 \%$ because of the level effect. ${ }^{12}$ In other words, the economy is investing more by reducing consumption in the short and medium run. This increase in the capital stock does not occur painlessly.

In order to better understand the impact of the parameters in our model we have also performed a comprehensive sensitivity analysis reported in the next eight rows of Table 3. The results in Table 3 indicate that the welfare estimates for the same tax cut ranged up to $-0.43 \%$ for $(K / Y)^{*}=1.5$, and down to $-0.77 \%$ for $g_{c} *=0.043$. The positive longrun impact upon consumption is also highest for $(K / Y)^{*}=1.5$. The sensitivity analysis illuminates the qualitative robustness of the results. The welfare effect and the impact effect upon consumption are negative, while the

12 Lucas (1990) has estimated that the welfare gain from the elimination of capital income taxation in the US would equal about $6 \%$ of annual consumption when transition effects are ignored, but less than $1 \%$ when transitional costs are taken into account. For comparison, Lucas (1990) notes that this is about 20 times the gain from eliminating postwar US business cycles. Subsequent papers by King and Rebelo (1990) and Jones et al. (1993) have tended to confirm these findings. 
long run impact upon consumption generally turns out to be positive.

Economic theory suggests that lower tax rates could boost investment and growth in several ways. Reducing tax rates might encourage people to work harder. This should boost both labour supply. In order to check robustness against consideration of an endogenous leisure-labour supply decision, we normalize household time to one, denote leisure by $x$, i.e. labour supply $l=1-x$, and rewrite the utility function (9) as

$$
U=\int_{0}^{\infty} \frac{\left(x^{\eta} C\right)^{1-\sigma}}{1-\sigma} e^{-\rho t} d t,
$$

where $\eta$ measures the impact of leisure on utility. Wage income changes to $l w$. According to standard RBC-modelling we set pre-reform labour supply to 0.33 of total time and obtain the supply elasticity endogenous. For benchmark parameters and steady-state values this provides the estimate $\eta=1.67 .^{13}$

Households now react to increasing productivity and wages caused by the tax reform by supplying more labour. Higher labour income cushions the fall of consumption on impact and allows for higher steady-state consumption. While utility tends to rise in response to these effects, increasing working time and less leisure tend to depress utility. Altogether the reform changes steady-state employment by 0.45 percentage points. The results shown in the ninth row of Table 3 (beginning with $\eta=$ 1.67) indicate a significantly stronger impact of the reform on long-run consumption (and to a somewhat lesser degree on long-run welfare). Yet the net welfare change caused by the reform is not much affected by consideration of endogenous leisure. These findings are robust against alternative estimates of the labor supply elasticity. The Table shows results for one alternative parameterisation assuming that only 0.25 of total time is employed prior the reform. This implies $\eta=2.48$ and an increase of employment by 0.25 percentage points due to the reform as shown in row 10 (beginning with $\eta=2.48$ ) in Table 3 .

13 The solution of the household maximisation problem is described in detail in Strulik (2003b).
Finally, we check how results are affected by an alternative assumption about the path of government expenditure. For that purpose, we continue to assume a value of $\mathrm{g}(0)=0.2$ prior to the reform but government expenditures vary afterwards. Instead of fixing the government share, we now assume that government expenditure $G$ grows at the exogenous steady-state growth rate $\gamma$ at all times. Thus, G/A is constant at

$$
\tilde{g}=\frac{G(0)}{A(0)}=g(0) k(0)^{\alpha} \text {. }
$$

The new equation of motion becomes

$$
\frac{\dot{k}}{k}=k^{\alpha-1}-c-\delta-\frac{\tilde{g}}{k}
$$

The final row in Table 3 shows the calibration results for this scenario. Because the government does not claim a (constant) share of marginal $G D P$, the tax reform is (implicitly) used to cut down the government share of GDP, leading to a decrease of $g$ from 0.2 to 0.194 . The cut of public expenditure has an additional expansive effect on private expenditure that cushions the initial drop of consumption and approximately doubles the long-run consumption effect. Consequently, the net gain of the reform becomes (slightly) positive. ${ }^{14}$ Alternatively, this scenario can be thought of as a two-step policy reform where the first step consists of the abolishment of a distortionary tax (the effects and efficiency gains of which are shown in the first row in Table 3), and the second step consists of a reduction of the total tax burden, i.e. a cut of the government share of GDP (the effects of which are obtained by subtracting the first from the last row in Table 3).

We also summarise the transitional dynamics in Figure 1. To compute the transitional dynamics, we use the backward integration procedure of Brunner and Strulik (2002) to rule

14 The separation of welfare effects into steady-state gain and transitional gain is now ambiguous. The steady-state gain is calculated as 1.85 percent if one compares the prereform steady state supported by the pre-reform government share with the after-reform steady state supported by the new government share. Yet, if one accounts for the reduced government share as a structural break, the welfare gain of a tax reform that supports $\mathrm{g}=0.194$ before and after the policy change is calculated as 0.89 percent. Of course, transitional effects adjust accordingly leaving the net effect unaffected by the separation issue at 0.08 percent. 
$k$

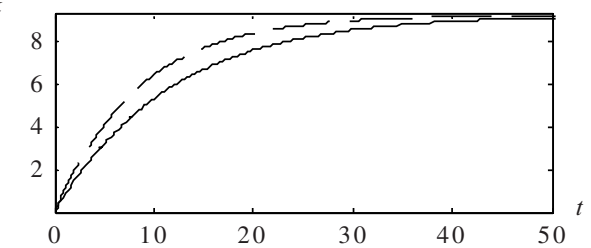

$I / Y$

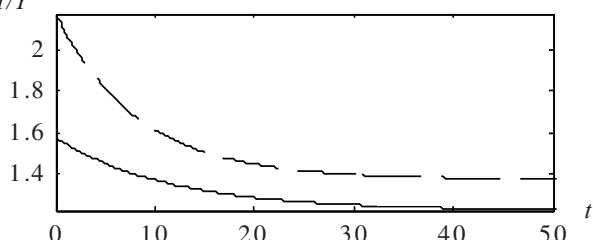

C

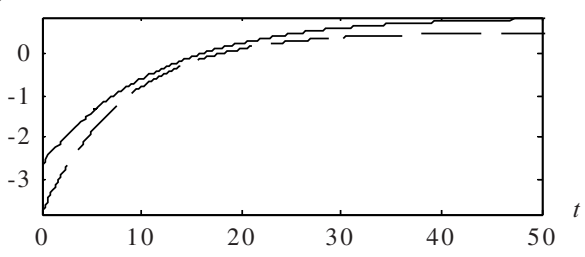

$g$

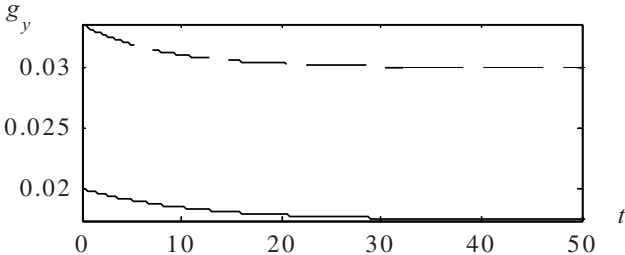

Figure 1. Transitional Dynamics for the Benchmark Model

Note: The solid lines represent $g_{c^{*}}=0.0175$ (benchmark case), the dashed lines represent $g_{c^{*}}=0.03$.

out explosive behaviour. The procedure uses the backward stability of the stable manifold and the fact that state variables cannot jump. The analysis begins arbitrarily close to the post-reform steady state and integrates (15) and (16) backwards until the capital stock $k$ reaches its pre-reform steady state. A second revision of time then provides the forward-looking solution using Runge-Kutta methods.

A few comments are in order. The simulation starts in period 0, where the government suddenly changes the tax rates. This unanticipated policy shock induces a reaction from all economic variables. Figure 1 shows the time paths of $k$ and $c$ expressed as percentage deviations from the pre-reform state. Deviations of $I / Y$ from pre-reform steady states are given in percentage points. The capital stock increases by $9.24 \%$ because the 2000 income tax act provides a more favourable tax treatment for investment. ${ }^{15}$ The immediate and medium-run impact upon consumption is negative (crowding-out effect). While consumption increases in the long run, the lower income tax does not increase overall welfare: the equivalent variation corresponding to it is slightly negative. This implies that the effect of taxation in a dynamic setting is more subtle than often supposed. In particular, we need to distinguish between the short-term im-

15 This increase is slightly more pronounced than the increase in Funke (2002). pact and the effects upon the steady-state levels. The increase in GDP is brought about by higher investment. This requires lower consumption, particularly in the early years of the simulation, and lowers welfare. In other words, the results remind us that increasing investment does not necessarily increase welfare - higher consumption in the long run can only be achieved at the cost of lower consumption in the present. And so a trade-off has to be made. The final graph indicates that the growth rate of the economy $\left(g_{y}\right)$ increases during transition dynamics. Over time, however, the growth rate gradually declines and converges again to the (exogenous) growth rate.

As an additional thought experiment, one can interpret the immortal representative individual as a dynasty, where an individual born $s$ years after the tax reform has utility $\int_{s}^{\infty} U(C(t)) e^{-\rho t} d t$. This modification allows us to identify the welfare winners and welfare losers after the reform. In Figure 2 we assume that a new generation is born every year. For the sake of brevity, we present only the results for the benchmark case. The results indicate that the current generation bears the main burden of the reform. As time goes by, the lifetime welfare effects resulting from the tax reform turn out to be positive. The break-even occurs approximately at $t=5$. Generations born six years after the reform already enjoy beneficial welfare effects. In order to facilitate the implementation of the Estonian tax 


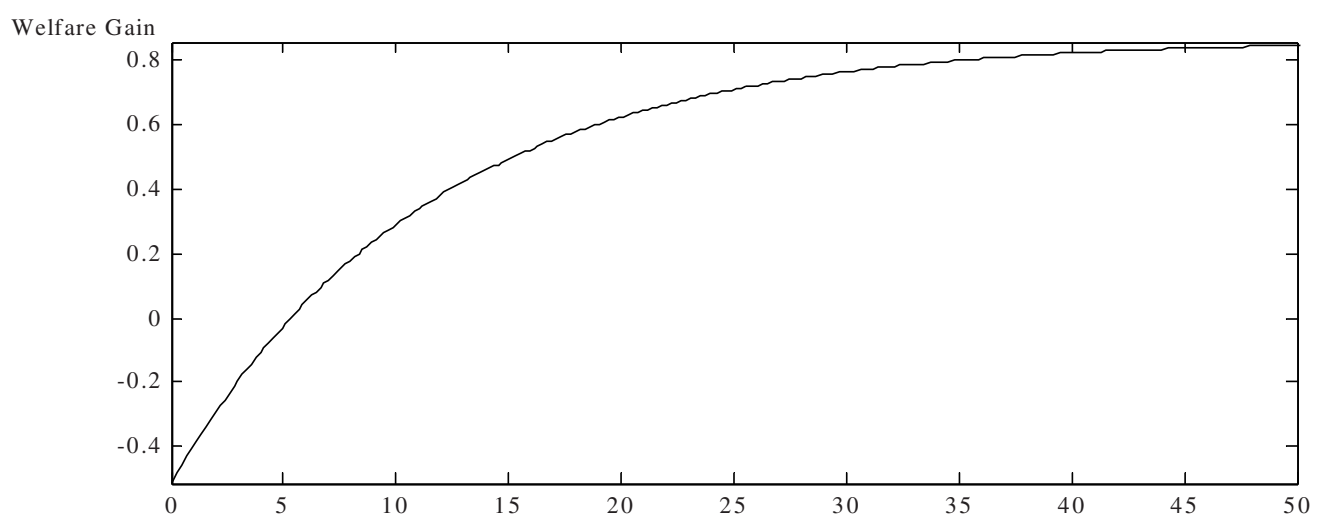

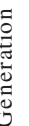

Figure 2. Generational Distribution of Welfare Gains and Losses

reform in more inclusive voting mechanisms, those making decisions today have taken the welfare of future generations into account.

The graph indicates that the country is facing the problem of determining the optimal tradeoff between consumption and investment across generations. This conclusion is important for policy purposes. Clearly, the choice of a tax reform strategy plays a critical part in meeting wider generational and social objectives.

\section{Foreign direct investment}

The three-sector model used in section 5 clearly offers plenty of opportunities for improvement. One can argue, for example, that the results are incomplete since our benchmark model is for a closed economy, i.e. Estonia is assumed to live in financial autarky and therefore investment expenditures have to be financed by the sacrifice of domestic consumption over time. Thus, we now consider an augmented open economy version of our model by allowing for foreign direct investment $(F D I) .{ }^{16}$ As a result of

16 To keep things tractable, we overlook all aspects of maximization in the Rest-of-the-World. This would complicate the model without providing additional insights for the purpose at hand. Hines (1999) and the OECD (2001) have shown the increasing sensitivity of FDI to country tax burdens, consistent with trends towards globalisation. Agreements on the avoidance of double taxation of income and capital, based on the OECD model agreement, have been the international integration of capital markets and the assumption that Estonia constitutes a small open economy, the interest rate is set by global economic developments rather than by domestic factors. For our numerical exercise we therefore assume that the world interest rate $r^{w}$ is constant. The steady-state capital stock is now obtained as

$$
k^{*}=\left[\frac{(1-m) r^{w}+\phi \delta}{\alpha \phi}\right]^{1 /(\alpha-1)}
$$

which replaces (18). We neglect adjustment costs so that domestic interest rates converge with infinite speed towards $r^{w}$ and (25) holds at all times. Let's assume that $r^{w}$ coincides with the pre-reform interest rate under autarky and that the share of foreign firms hold by Estonians is negligible. Because domestic investment rates cannot be infinite (this would violate the consumers first order conditions), the instantaneous increase of the capital stock $k^{*}$ caused by the corporate tax reform (i.e. the increase of $\phi$ to 1) is solely financed by a spontaneous influx of foreign capital. In other words, perfect capital mobility eliminates all transitional effects

concluded between Estonia and the following countries: Belarus, Canada, China, the Czech Republic, Denmark, Finland, Germany, Iceland, Ireland, Latvia, Lithuania, Moldova, the Netherlands, Norway, Poland, Sweden, Ukraine, the United Kingdom and the US. Agreements with France and Italy await ratification. 
Finnish Economic Papers 1/2006 - Michael Funke and Holger Strulik
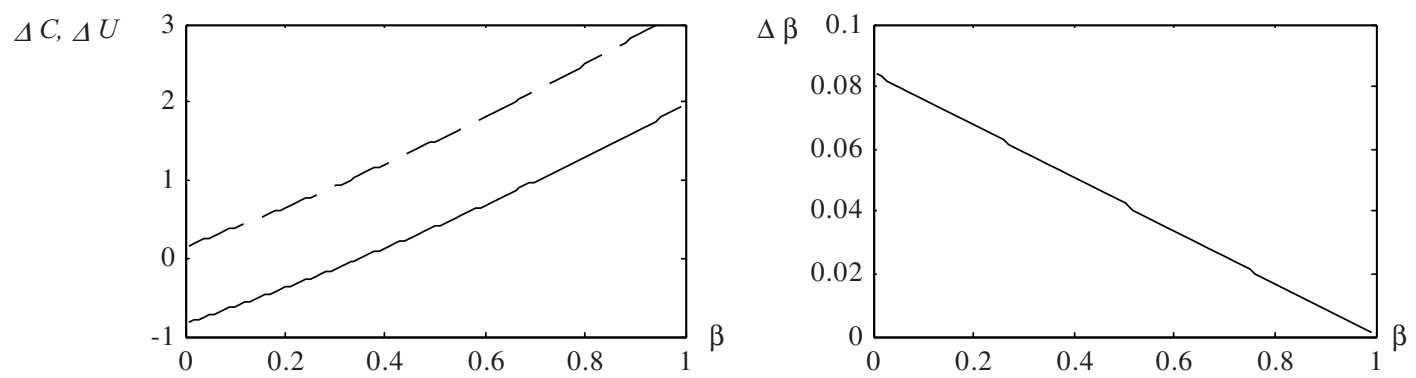

Figure 3. Percentage Welfare Gain and Capital Dilution under FDI

Note: The solid lines represent the benchmark scenario, the dashed lines represent the alternative scenario (constant government expenditure growth rate)

and $G D P$ adjusts to the higher level painlessly for the Estonian consumer.

From the absence of adjustment dynamics we cannot yet conclude a higher welfare gain under the FDI scenario. The capital influx dilutes the share of capital hold by Estonians and decreases the tax revenues from capital taxation relative to government spending. In order to finance the share $\mathrm{g}$ of GDP the government has to adjust expenditures by lowering transfers to consumers. Which effect dominates depends on how much government finance relied on private capital income taxation before the reform, which in turn depends on the share of capital hold by Estonians before the reform. In order to elaborate this trade-off quantitatively, let $\beta$ denote the pre-reform share of the Estonian capital stock held by foreigners. Thus GDP is used for

$$
\begin{aligned}
& Y=C+G+I+\delta K+\beta D \Rightarrow(1-g) Y \\
& =C+I+\delta K+\beta(Y-w-\delta K-I / \phi) .
\end{aligned}
$$

Solving for $I / K$ and imposing the steady-state condition $I / K=\gamma$ provides consumption$$
c^{*}=(1-g-\alpha \beta) k^{* \alpha-1}-\delta(1-\beta)-\frac{\gamma(\phi-\beta)}{\phi}
$$

Solid lines in Figure 3 show the gain in consumption and welfare (which coincide because of absent transitional dynamics) for benchmark parameters and alternative $\beta$ 's. FDI raises the foreign share of capital by $\Delta \beta$. This effect is largest if foreigners had no stake in Estonian capital prior to the reform and vanishes when the complete Estonian capital stock is owned by foreigners $(\beta=1)$. Because FDI lowers the capital stock held by Estonians relative to GDP it reduces the share of government expenditure financed by private capital income taxation. It entails lower transfers in order to maintain a constant government share. This negative effect is the higher the more public finance relied on revenue from capital income taxation before reform. It is absent for $\beta=1$, which thus accords with the highest welfare gain from the reform. For $\beta$ 's of empirically relevant magnitudes between 0.2 and 0.3 the tax effect slightly dominates the gross income effect yielding the estimates between -0.4 and -0.2 for the welfare gain which comes close to our original estimate of -0.5 for the closed economy under transitional dynamics. ${ }^{17}$ Dashed lines show welfare gains for an optimistic scenario for which the assumption of a constant government share is again replaced by constant government expenditure growth at rate $\gamma$. In this case the welfare gain is substantially higher and lies between 0.6 and 0.8 percent for $0.2<\beta<0.3$ because the tax reform is simultaneously used to cut down the government share (from 0.2 to 0.194 ).

$170.2<\beta<0.3$ is consistent with the net inflow of foreign direct investment into Estonia. Estonia is one of the few transition economies with sufficient FDI outflows to produce a significant difference between the gross and net figures. At the beginning of the 1990s, FDI in the Baltic states was closely correlated with privatisation receipts. More recently, the Baltics have begun to attract substantial non-privatisation-related FDI inflows. See EBRD (2001, 2003). 
Finnish Economic Papers 1/2006 - Michael Funke and Holger Strulik

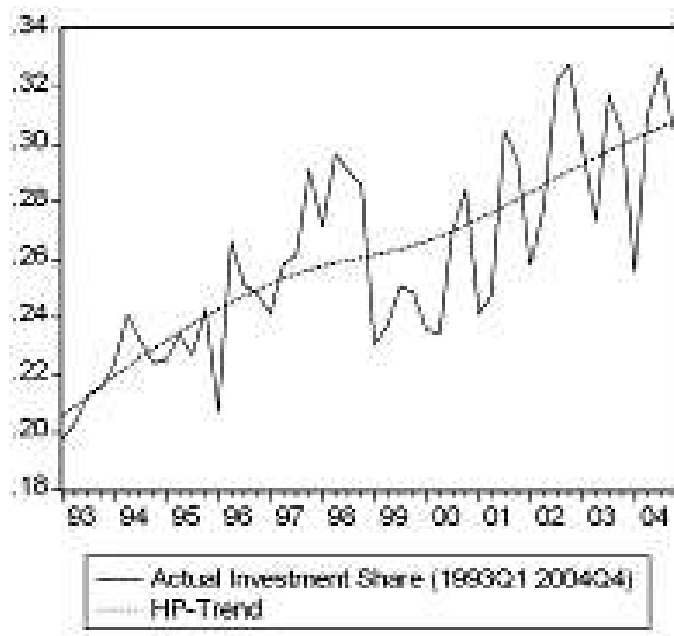

Figure 4: Estonian Investment Share (Gross Investment/ GDP) in \%, 1993Q1 - 2004Q4

\section{Confronting the theoretical under- pinnings with empirical data}

Modelling and calibration exercises of the type presented in this paper are usually done in order to analyse the effects of a hypothetical policy reform. In this case, however, we are considering an actual reform which took place some years ago. Hence, it is natural to present some descriptive empirical evidence about the effects of the Income Tax Act 2000. Is there empirical evidence to support the calibration results? Figure 4 presents the Estonian investment share from 1993Q1 to 2004Q4. It would, however, be misleading to rely too much on the raw data because investment spending is affected by any number of things, notably the timing of the business cycle. To get a more accurate picture, we therefore also present the HP-filtered trend investment share. ${ }^{18}$

The important message is that the trend investment share has, if anything, accelerated after 2000, while the investment ratio started to abate at the end of the 1990s. In other words, Estonia has witnessed a fresh investment spurt, not least thanks to the year 2000 tax reform act.

18 The HP-filtered series has been calculated with $\lambda=1600$.

\section{Conclusions}

We have constructed and calibrated a dynamic general equilibrium growth model that could offer plausible predictions about the impact of Estonia's 2000 income tax reform. Overall, the model suggests that the tax reform benefits the investment climate and fares quite favourably in the long run.

The reform's effect on consumption and welfare depends significantly on transitional dynamics and on whether the government holds constant its share of GDP or whether the efficiency gain from lower taxation is used to cut back government consumption. Only in the latter case is the net welfare gain positive when transitional dynamics are taken into account. Hopefully, our investigation will pave the way for further empirical work aimed at identifying tax impacts upon investment spending of firms in Estonia.

\section{References}

Brunner, M., and H. Strulik (2002). "Solution of Perfect Foresight Saddlepoint Problems: A Simple Method and Applications." Journal of Economic Dynamics and Control 26, 737-753.

Chamley, C.P. (1981). "The Welfare Cost of Capital Income Taxation in a Growing Economy." Journal of Political Economy 89, 468-496.

-.-- (1986). "Optimal Taxation of Capital Income in General Equilibrium With Infinite Lifes.” Econometrica 54, 607-622.

Coleman, W.J. (2000). "Welfare and Optimum Dynamic Taxation of Consumption and Income." Journal of Public Economics 76, 1-39.

EBRD (2001). Transition Report Update. London.

---- (2002). Transition Report 2002. London.

-.-. (2003). Transition Report Update. London.

Ebrill, L., and O. Havrylyshyn (1999). Tax Reform in the Baltics, Russia, and Other Countries of the Former Soviet Union. IMF Occasional Paper \# 182, Washington.

Funke, M. (2002). "Determining the Taxation and Investment Impacts of Estonia's 2000 Income Tax Reform." Finnish Economic Papers 15, 102-109.

Hall, R.E. (1988). "Intertemporal Substitution in Consumption.” Journal of Political Economy 96, 330-357.

Hines, J.R. (1999). "Lessons from Behavioural Responses to International Taxation." National Tax Journal 54, 305-323.

IMF (2000). "Republic of Estonia: Statistical Appendix." IMF Staff Country Report No. 00/102. Washington, D.C.

Jones, L.E., R.F. Manuelli, and P.E. Rossi (1993). "Optimal Taxation in Models of Endogenous Growth." Journal of Political Economy 101, 485-517. 
Finnish Economic Papers 1/2006 - Michael Funke and Holger Strulik

Judd, K.L. (1987). “The Welfare Cost of Factor Taxation in Perfect Foresight Model." Journal of Political Economy 95, 675-709.

Kesti, J. (1995). "Estonia: Taxation of Companies and Individuals." European Taxation 35, 193-197.

King, M.A. (1977). Public Policy and the Corporation. London: Chapman \& Hall.

King, M.A., and D. Fullerton (1984). The Taxation of Income from Capital - A Comparative Study of the United States, the United Kingdom, Sweden, and West Germany. Chicago: The University of Chicago Press.

King, R.G., and S.T. Rebelo (1990). "Public Policy and Economic Growth: Developing Neoclassical Implications." Journal of Political Economy 98, S126-S150.

Lucas, R.E. (1990). "Supply-Side Economics: An Analytical Review." Oxford Economics Papers 42, 293-316.

-.-- (2003). "Macroeconomic Priorities." American Eco nomic Review 93, 1-15.

Myers, S.C., and N.S. Mailuf (1984). "Corporate Financing and Investment Decisions When Firms Have Information that Investors Do Not Have." Journal of Financial Economics 13, 187-221.

Nam, C.W., and D.M. Radulescu (2003). The Role of Tax Depreciation for Investment Decisions: A Comparison of European Transition Countries. CESifo Working Paper No. 847, Munich.

OECD (2001). Corporate Tax Incentives for Foreign Direct Investment. Paris.

Ogaki, M., and C.M. Reinhart (1998). "Measuring Intertemporal Substitution: The Role of Durable Goods." Journal of Political Economy 106, 1078-1098.

Rõõm, M. (2001). Potential Output Estimates for Centra and East European Countries Using Production Function Method. Bank of Estonia Working Paper \# 2/2001, Tallinn

Sinn, H.W. (1987). Capital Income Taxation and Resource Allocation. Amsterdam: North-Holland.

Sorainen, A., T. Klauberg, E. Berlaus, and T. Davidonis (2002). A Foreign Investor in the Baltics 2002. Helsinki: Finnish Lawyers' Publishing.

Stepanyan, V. (2003). Reforming Tax Systems: Experience of the Baltics, Russia, and the Other Countries of the Former Soviet Union. IMF Working Paper WP/03/173, Washington.

Strulik, H. (2003a). "Supply-Side Economics of Germany's Year 2000 Tax Reform: A Quantitative Assessment." German Economic Review 4, 183-202.

-.-- (2003b). "Capital Tax Reform, Corporate Finance, and Economic Growth and Welfare." Journal of Economic Dynamics and Control 28, 595-615.

World Bank (2000). Transition - The First Ten Years. Washington, D.C. 